\title{
기후변화 관련 최근 원조 현황과 논의 방향(3) ${ }^{1)}$ - 신재생에너지 분야 -
}

\author{
임소영 · 박희수 한국국제협력단 기후변화대응반 연구관
}

\section{I. 서론}

세계를 움직이는 에너지는 19 세기에는 석탄, 20 세기에는 석유로부터 비롯되었다. 그 동안의 화석 연료 중심의 경제·산업 구조가 야기해 온 기후변화, 환경문제, 자원고갈의 우려, 에너지안보 위 협 등의 문제로 말미암아 곤경에 처해 있는 21 세기는 지금까지의 형태와는 완전히 다른 새로운 패 러다임의 에너지를 필요로 하게 되었다. 이에 전 세계가 개발 및 보급에 주력하고 있는 새로운 에너 지 대안이 태양, 바람 등 지속적으로 자연에서 얻을 수 있는 재생에너지(renewable energy)이다. 여기에 수소에너지, 연료전지, 석탄가스화복합발전 등 인간이 새롭게 개발하여 에너지로 사용할 수 있는 신에너지 (new energy)를 포함하여 신재생에너지(new and renewable energy) ${ }^{2}$ 라는 용어 가 생기게 되었다.

지금까지 재생에너지와 관련된 논의는 주로 선진국을 중심으로 하는 기술개발에 초점이 맞추어져 있었다. 특히 21세기 초반부터 지속되어 온 고유가 추세 및 교토의정서에 의해 부여된 1990년 대 비 평균 $5.2 \%$ 라는 온실가스 감축의 의무는 선진국들의 재생에너지 개발을 가속화시켰다. 그러나 전 세계의 기후변화안정을 위해 개발도상국, 특히 신흥국가들의 온실가스 감축을 위한 공동노력 이 절실히 요구되면서 개발도상국에 대한 재생에너지 지원이 국제사회의 중요 이슈가 되었다. 실 제로 OECD 비회원국들이 차지하던 전 세계 이산화탄소 배출 비율은 1973년 34.2\%에서 2007년 $55.1 \%$ 로 증가하였다 (IEA, 2009). 이에 현재의 기후변화에 대한 역사적 책임은 거의 없지만 갈수 록 많은 양의 온실가스를 배출하고 있는 개발도상국들의 경제발전을 저해하지 않는 범위에서, 기후

1) 본 보고서는 『국제개발협력』2009년 2호, 3 호에 기재된 물 분야, 민관협력에 이어 시리즈로 진행된 기후변화 분석 보고 서입니다.

2) "신에너지 및 재생에너지 개발.이용·보급 촉진법(1987.12.4 제정, 2009.5.21 개정)"에 의해 기존의 화석연료를 변환시켜 이용하거나 햇빛·물·지열·강수·생물유기체 등을 포함하는 재생가능한 에너지를 변환시켜 이용하는 에너지라 정의됨. 동 법 에서 태양에너지, 생물자원을 변환시켜 이용하는 바이오에너지, 풍력, 수력, 연료전지, 석탄을 액화·가스화한 에너지 및 중질잔사유를 가스화한 에너지, 해양에너지, 폐기물에너지, 지열에너지, 수소에너지, 그 밖에 석유·석탄·원자력 또는 천연 가스가 아닌 에너지로서 대통령령이 정하는 에너지가 해당 범위로 제시됨. 
변화 문제를 공동으로 해결하기 위한 이들의 참여를 유도하기 위하여 지속가능한 재생에너지 지원 의 필요성이 제기되었다.

본고는 개발도상국에 대한 신재생에너지 지원의 필요성을 검토하고, 주요 공여국과 공여기관들의 신재생에너지 지원 동향 및 전략을 고찰하여 우리나라 ODA에서 신재생에너지 지원의 위치를 확인 하고 방향을 설정하고자 하였다.

\section{II. 신재생에너지 지원의 필요성}

\section{1. 새천년개발목표 (MDGs)와 신재생에너지}

에너지 부문 서비스는 비록 MDGs에 명시적으로 언급되지는 않았지만, 전 세계 개발도상국들의 개 발을 위한 노력 및 생활 여건의 개선을 위하여 결정적인 역할을 한다는 사실에 일반적인 동의를 얻 고 있다. 특히 신재생에너지는 빈곤층에게 더욱더 불리하게 작용하는 화석연료에 대한 지나친 의존 성을 완화함으로써 MDGs 달성에 기여할 수 있다 (표 1).

\section{가. MDG1 : 절대빈곤 및 기아 퇴치}

개발도상국들의 빈곤층이 사용하는 에너지 서비스의 약 $80 \%$ 는 음식 조리를 위한 연료로 소비되며, 월 소득의 $20 \%$ 이상이 목재나 숯을 구입하기 위하여 지불된다. 특히 연료용 목재를 구하기 위하여 하루 5시간에 해당하는 노동을 담당하는 주된 주체는 여자 어린이들로서, 에너지 문제로 인한 성 불평등 심화 현상도 발견된다. 이렇듯 조리 및 난방용 연료가 빈곤층에서 차지하는 중요성을 고려 할 때, 신재생에너지를 이용한 적정기술 ${ }^{3)}$ 을 조리 또는 난방에 적용하거나 연료의 효율을 개선하는 것으로도 노동에 대한 부담 및 비용을 상당히 경감시킬 수 있으며, 결과적으로 빈곤층의 또 다른 소 득 창출 및 교육의 기회를 넓힐 수 있게 된다.

개발도상국 농촌 격지에 제공되는 전력을 생산하기에 가장 적절한 재생에너지원은 태양광, 바이오 가스, 소규모 풍력터빈, 소수력 시스템이다. 이들로부터 생산되는 전기는 주로 농촌 지역의 조명을 위해 사용되며, 야간 시간의 가내수공업 및 자율학습을 가능하게 함으로써 주민들의 소득수준을 향 상시킬 수 있다. 또한 재생에너지로부터 생산된 전력을 사용하는 펌프는 보다 더 안전한 식수 및 관

3) 개발도상국의 지역적 조건에 맞는 기술로서, 선진국들로부터 직수입된 근대 과학기술이 아닌 자립경제의 관점에서 모색된 새로운 기술 개념 
개용수를 공급하여 지역의 보건 및 농업생산성 향상에 기여한다.

\section{나. MDG2 : 보편적 초등교육 달성}

학교에서 컴퓨터, 복사기 등 신기술을 사용하기 위해서는 전기가 필요하다. 또한 숙련되고 전문성 있는 교사들도 컴퓨터 등 관련된 제반시설이 잘 갖추어져 있는 학교에 근무하기를 더 선호한다. 따 라서 개발도상국 학생들이 지속적으로 교육을 받기 위해 필요한 교사 및 전기제품의 제공이 유지되 기 위해서는 재생에너지를 중심으로 하는 안정된 에너지 공급이 필요하다. 즉 에너지는 개발도상국 농촌 지역의 지속가능한 경제발전 및 도시지역으로의 이주를 감소시킬 수 있는 교육과 기술 사이의 간극을 좁힐 수 있는 매개체 역할을 하게 된다.

\section{다. MDG3 : 남녀평등 및 여성권익 향상}

세계 인구의 약 3 분의 1 이 음식조리를 위해 여전히 전통적인 바이오매스를 연료로 사용하고 있으 며, 질 낮은 연료의 사용으로 발생하는 실내공기오염 및 건강악화 문제는 여성들의 몫으로 돌아간 다. 따라서 신재생에너지를 이용한 청정연료는 실내공기 질을 개선하여 여성들의 건강 증진에 기여 한다. 이 외에도 신재생에너지는 농촌 지역 여성들의 목재 수집, 우물 긷기, 비효율적인 음식 조리 등의 노동에 대한 부담을 줄임으로써 이들의 교육 및 여타 경제 활동의 기회를 제공할 수 있다.

\section{라. MDG4, 5, $6:$ 아동 사망률 감소/ 모성 보건 향상/ HIV/AIDS, 말라리아 및 기타 각종 질병 퇴치}

개발도상국의 가정에서 사용하는 바이오매스 연료 및 석탄에서 발생하는 연기는 실내공기오염을 증가시키며, 이는 5 세 이하 유아의 급성 호흡기 감염과 성인들의 만성폐쇄성폐질환 및 폐암을 유발 하는 요인이 된다. WHO의 세계보건보고서 (World Health Report)에 의하면, 실내공기오염에 의 해 연간 160 만 명 이상의 사망자가 발생하고 전 세계 질병의 $2.7 \%$ 가 유발된다고 한다. 이러한 수 치는 사망이나 질병을 일으키는 환경적인 요인들 중 ‘비위생적인 식수’ 다음으로 실내공기오염이 인간건강에 큰 영향을 미치고 있다는 사실을 시사하고 있다. 따라서 가정 내의 조리 및 난방용 연료 를 재생에너지로 전환함으로써 보건 향상 및 사망률 감소를 얻을 수 있게 된다.

풍토병 및 수인성 질병 등 공중보건을 결정짓는 가장 중요한 요소인 물 및 위생 부문도 신재생에너 지를 이용하여 개선할 수 있다. 예컨대, 신재생에너지를 이용한 식수용 펌프 및 살균 · 소독 처리를 하게 되면 횔씬 안전한 식수를 공급받게 된다. 


\section{마. MDG7 : 지속가능한 환경 보전}

$\mathrm{MDG}$ 가 구체화하고 있는 지속가능한 환경의 지표는 에너지효율, 이산화탄소 배출, 산림면적 비율 등이다. 이들 지표들은 모두 기후변화 완화와 관련된 요소들이며, 신재생에너지를 이용하여 개선할 수 있는 지표들이다. 즉 태양이나 바람을 이용한 에너지원은 사용 과정에서 이산화탄소를 전혀 배 출하지 않으며, 기존의 목재 연료를 대체하기 때문에 산림벌채 필요성을 대폭 줄여 산림의 면적을 보존할 수 있다. 따라서 재생에너지는 대기 중의 이산화탄소 농도를 안정화 시키고 궁극적으로는 기후변화를 완화시키는 역할을 함으로써, 전 지구적인 환경보전에 기여하게 된다.

\section{바. MDG8 : 개발을 위한 범지구적 파트너십 구축}

신재생에너지는 개발 및 보급 과정에서 개발도상국 청년층을 위한 새로운 일자리 및 시장을 창출한 다. 또한 지속적인 신재생에너지 기술의 개발은 민간부문의 참여를 유도하여 민간부문과의 협력을 촉진하는 계기를 마련한다.

〈표 1〉MDGs의 목표 달성을 위해 신재생에너지가 기여할 수 있는 범위

\begin{tabular}{|c|c|}
\hline 새천년개발목표 & 신재생에너지의 기여 가능 예시 \\
\hline $\begin{array}{c}\text { 목표 } 1: \\
\text { 절대빈곤 및 기아퇴치 }\end{array}$ & $\begin{array}{l}\text {. 빈곤층의 음식조리 및 난방용으로 사용되는 연료용 목재 및 솣을 대체함으로써 연료를 구하기 위한 노동 } \\
\text { 의 부담 경감 및 다른 경제활동을 위한 여유 시간 제공 } \\
\text {. 농촌 격지 가정의 조명을 위한 전력을 생산함으로써 야간 시간의 활용도를 제고하여 주민들의 소득수준 } \\
\text { 향상에 기여 } \\
\text {. 안정적인 관개용수를 제공하는 관개펌프에 필요한 전력을 생산함으로써 농가 생산성 향상 }\end{array}$ \\
\hline $\begin{array}{c}\text { 목표2: } \\
\text { 보편적 초등교육 달성 }\end{array}$ & $\begin{array}{l}\text { · 학교에 대한 안정된 에너지 공급으로 학생들의 지속적인 교육에 필요한 전기제품의 사용 및 숙련된 교사 } \\
\text { 확보가 가능 } \\
\text { 교육과 기술 사이의 간극을 좁힘으로써 개발도상국 농촌 지역의 지속가능한 경제발전 및 도시지역으로의 } \\
\text { 이주를 감소시키는 역할 }\end{array}$ \\
\hline $\begin{array}{l}\text { 목표3: } \\
\text { 남녀평등 및 } \\
\text { 여성능력 고양 }\end{array}$ & $\begin{array}{l}\text { 질 낮은 전통 연료의 사용으로 악화된 실내공기의 질을 개선하여 여성들의 건강 증진 } \\
\text {. 농촌 지역 여성들의 노동 (목재 수집, 우물 긷기, 비효율적인 음식 조리 등)에 대한 부담을 줄임으로써 여성 } \\
\text { 들의 교육 및 여타 경제 활동의 기회 제공 }\end{array}$ \\
\hline $\begin{array}{l}\text { 목표4: } \\
\text { 아동사망률 감소 } \\
\text { 목표 } 5: \\
\text { 모성보건 증진 } \\
\quad \text { 목표6: } \\
\text { 각종질병 퇴치 }\end{array}$ & $\begin{array}{l}\text { · 개발도상국 가정에서 사용하는 목재연료 및 석탄에서 발생하는 연기로 유발되는 유아의 급성호흡기 감염 } \\
\text { 과 성인의 만성폐쇄성폐질환 및 폐암의 발병을 감소시킴 } \\
\text { · 재생에너지로 생산된 전력을 사용한 식수용 펌프 및 살균 · 소독 처리는 안전한 식수 및 위생을 제공하여 } \\
\text { 수인성 질병을 감소시킴 }\end{array}$ \\
\hline $\begin{array}{l}\text { 목표7: } \\
\text { 지속가능한 환경보전 }\end{array}$ & $\begin{array}{l}\text {. 재생에너지는 사용 단계에서 온실가스를 전혀 배출하지 않으며, 기존의 목재 연료를 대체하기 때문에 산림 } \\
\text { 벌채 필요성을 줄여 대기 중의 이산화탄소 농도를 안정화 시키고 궁극적으로는 기후변화를 완화하는 역할 } \\
\text { 수행 }\end{array}$ \\
\hline $\begin{array}{c}\text { 목표8: } \\
\text { 범지구적 파트너십 구축 }\end{array}$ & $\begin{array}{l}\text { - 개발 및 보급 과정에서 전 세계 개발도상국 청년층을 위한 새로운 일자리 창출 } \\
\text { - 지속적인 기술개발은 민간부문과의 협력을 촉진하는 계기 마련 }\end{array}$ \\
\hline
\end{tabular}




\section{2. 전 지구적 온실가스 농도의 안정화}

산업화 시대 이전의 지구 온도 대비 $2^{\circ} \mathrm{C}$ 상승 ${ }^{4}$ 을 초과하지 않기 위해서는 1990 년의 이산화탄소 배 출량의 $50 \%$ 이상을 2050 년까지 감축해야 한다는 연구 결과가 발표되었다 (EC, 2007). 그러나 국 제에너지기구(IEA)의 기준 시나리오)에 따르면 2005년부터 2030년까지 전 세계 에너지 사용과 관 련된 이산화탄소 배출은 오히려 약 $45 \%$ 증가할 것으로 예상된다. 그 중에서 $97 \%$ 는 중국, 인도, 중 동 지역을 중심으로 하는 $\mathrm{OECD}$ 비회원국에서의 증가가 차지할 것으로 전망된다 (IEA, 2008). 실 제로 2006-2030 기간 동안 기준 시나리오에서 선진국의 화석연료 사용 증가는 거의 정체될 것이 라고 예측된 반면, 개발도상국의 에너지 수요 증가분의 약 $40 \%$ 는 석탄에서 비롯되어 이에 따른 온 실가스의 다량 배출이 예상된다 (그림 1). 심지어 선진국들이 2030년까지 온실가스 배출을 완전히 없앤다고 하더라도, 개발도상국의 배출만으로 지구 온도가 $2^{\circ} \mathrm{C}$ 상승할 것이라는 관측도 존재한다.

\section{〈그림 1〉 2006-2030년 기간 동안 기준 시나리오 하에서 에너지 수요 증가분의 구성}

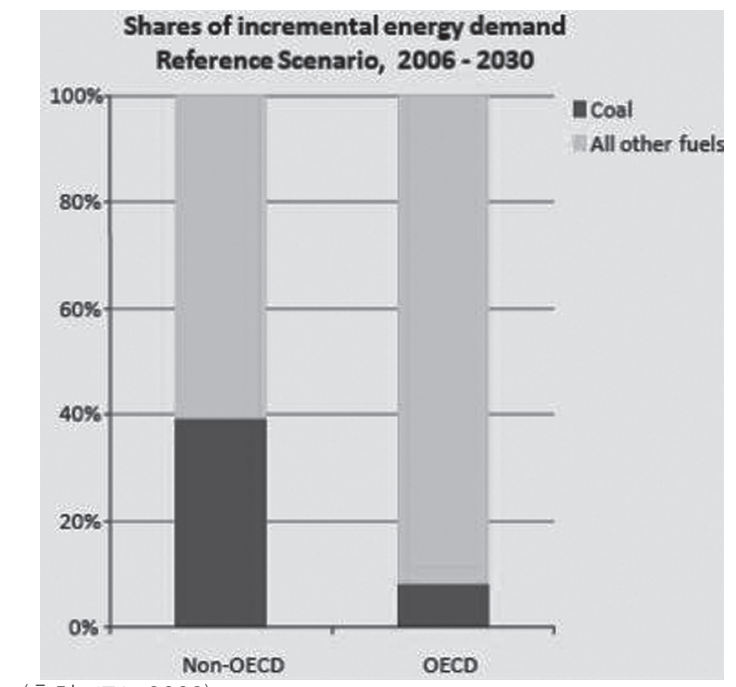

(출처: IEA, 2009)

이에 현재의 기후변화 현상에 대한 역사적 책임으로 인하여 교토의정서 하에서 평균 $5.2 \%$ 의 온실 가스 감축의 의무가 있는 기후변화협약 부속서I 국가들은 그 감축의무가 다하는 2012년 이후의 포 스트 교토체제에는 개발도상국들도 참여할 것을 강력하게 주장하고 있다. 그러나 개발도상국들은 선진국의 지속적이고도 영향력 있는 지원 없이는 온실가스 감축의 의무를 지지 않겠다는 입장에 있 다.

4) 초과 시 불가역적인 기후 재앙을 초래하는 온도의 임계 수준

5) 현재의 에너지 사용과 온실가스 배출 상황에 대한 대책을 전혀 세우지 않는 경우 
한편 현재 전 세계에서 전기의 혜택을 받지 못하는 인구는 모두 15 억 명으로 추산되며, 기준 시나 리오에서 에너지 사용의 증가 전망에도 불구하고 2030년 전기 미수혜자는 13 억 명에 달할 것으로 예측되어, 전기 공급이 크게 개선되지 못할 것임을 짐작할 수 있다 (그림 2). 에너지 부족 현상은 최 빈국이나 사하라 이남 아프리카 지역에서 점점 더 심각하게 발생할 것으로 예상되며, 결과적으로는 빈곤을 더 심화시키는 악순환이 일어날 것이다. 따라서 이들 지역에 대해서는 여타 다른 지역과는 달리 지역의 특성을 고려한 접근법으로 지원이 이루어져야 할 필요가 있다. 특히 중앙 전력망의 혜 택을 받지 못하는 개발도상국 격지의 농촌지역에서는 독립형 전기 시스템의 적용이 적절하며, 독립 형 시스템을 위해서는 화석연료보다 신재생에너지를 사용하여 최적의 모델을 고안할 수 있다.

\section{〈그림 2〉 2008년 현재 전기의 혜택을 받지 못하는 전 세계 인구 수 및 2030년 예측치}

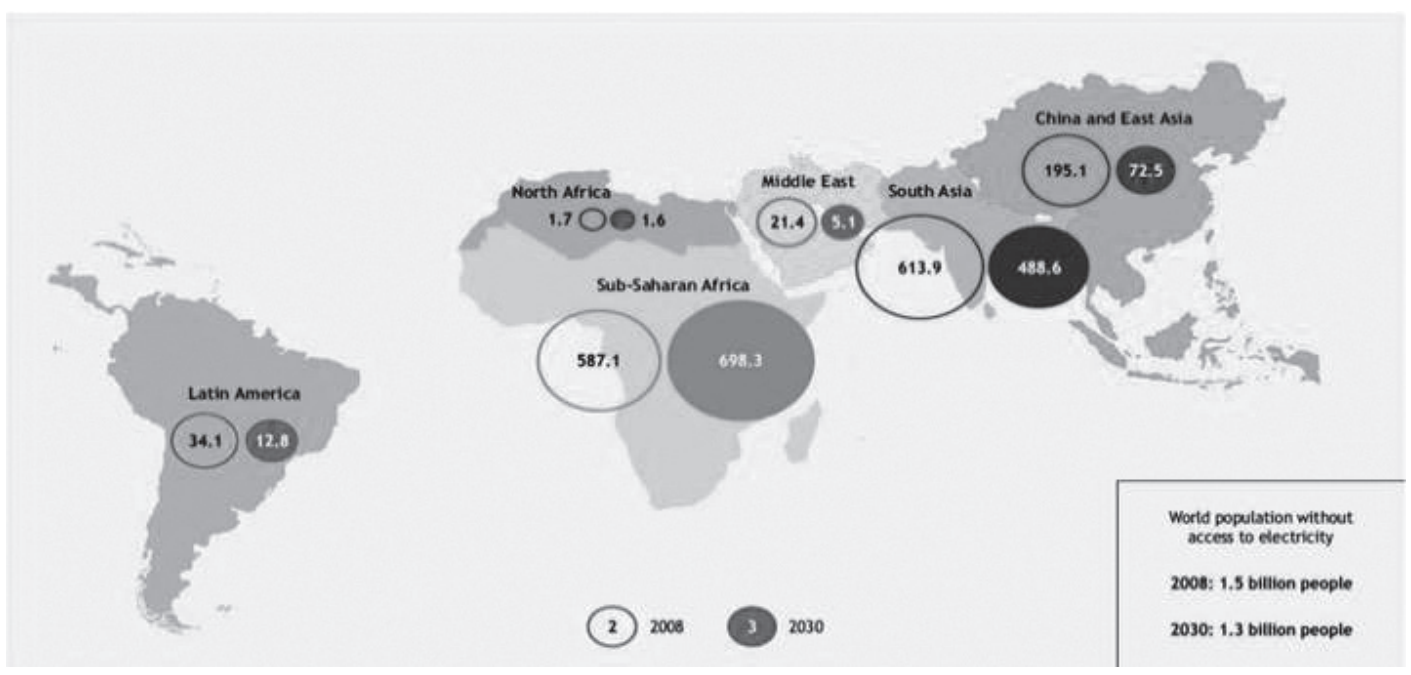

출처: IEA, 2009

\section{III. 주요 다자기구의 지원 동향 및 전략}

\section{1. 세계은행}

2004년 독일의 본(Bonn)에서 개최된 '2004 재생에너지 컨퍼런스 (Conference on Renewable Energy)'에서 세계은행은 재생에너지와 에너지효율 분야의 지원을 확대하겠다고 발표하였다. 이를 위해 Bonn Target이라는 구체적인 목표치를 설정하였는데 Bonn Target은 2005년에서 2009년 동안 매해 평균 $20 \%$ 씩 지원을 증액하겠다는 계획으로 세계은행은 대규모 수력발전도 경제적이고 재정적으로 타당성이 있으며 특히 환경적인 측면과 사회적인 측면에서 보호장치가 있다면 이의 설 
립도 추진하겠다고 공표하였다(World Bank, 2006a).

회계연도 2006년의 세계은행의 지원현황을 살펴보면 신재생에너지, 대규모 수력발전, 에너지 효 율 등 에너지 분야에서의 저탄소지원은 모두 8억 6,800 만 달러이며 이 자금은 34 개국에서 61 개의 프로젝트를 진행하는데 투입된 것으로 이 중 대규모 수력을 포함한 재생에너지 지원은 4억1,200만 달러이다 (표 2). 신재생에너지 지원과 에너지효율 지원의 합은 6억6,800만 달러로 이 금액은 회계 연도 2005년에 비해 45\% 증가한 수치로 매해 $20 \%$ 성장을 추진하는 Bonn Target을 두배 이상 초 과한 것이다(World Bank, 2006b).

세계은행 그룹 중에서 에너지효율을 포함한 에너지 분야에서 온실가스 감축을 지원해온 가장 큰 기 관은 IBRD, IDA, IFC이다. IBRD와 IDA는 대규모 수력을 포함한 재생에너지 분야의 지원을 위해 자체 자금 2 억 5,430 만 달러를 2006 년에 투입하였으며 IFC는 동일 기간에 자체 자금 8,440 만 달러 를 재생에너지 관련 사업에 사용하였다. MIGA(Multilateral Investment Guarantee Agency)는 2006년에 에너지 효율 분야에만 180만 달러를 지원하였다(World Bank, 2006b).

〈표 2〉 세계은행 그룹의 신재생에너지 지원 금액 (회계연도 2006년, 백만불)

\begin{tabular}{|c|c|c|}
\hline & 신재생에너지 & 수력>10MW \\
\hline World Bank (IBRD/IDA) & 135.7 & 118.6 \\
\hline World Bank(GEF \& Carbon Finance) & 54.7 & 6.0 \\
\hline IFC (Own Funds) & 17.4 & 67.0 \\
\hline IFC (GEF, Carbon Finance and other trust funds) & 13.0 & 0.0 \\
\hline MIGA & 0.0 & 0.0 \\
\hline Total & 220.8 & 191.6 \\
\hline
\end{tabular}

출처: World Bank, 2006b

IBRD와 IFC는 모두 탄소금융부 (Carbon Finance Unit)를 가지고 있으며 교토의정서 하의 청정개 발체제 $(\mathrm{CDM})$ 와 공동이행제도(JI)에 해당하는 프로젝트를 위한 공공과 민간의 투자를 끌어들이기 위해 노력하고 있다. 세계은행의 탄소금융부는 약 19 억 달러에 해당하는 아홉 개의 탄소 펀드를 운 영하며 재생에너지는 전체 포트폴리오의 $12 \%$ 를 차지한다. 회계연도 2006 년에 세계은행의 탄소금 융부는 재생에너지와 에너지 효율 부분에서 1,400 만 달러를 제공하였다(김대환 외, 2009). 
〈그림 3〉 세계은행그룹의 신재생에너지 및 에너지효율 지원 흐름

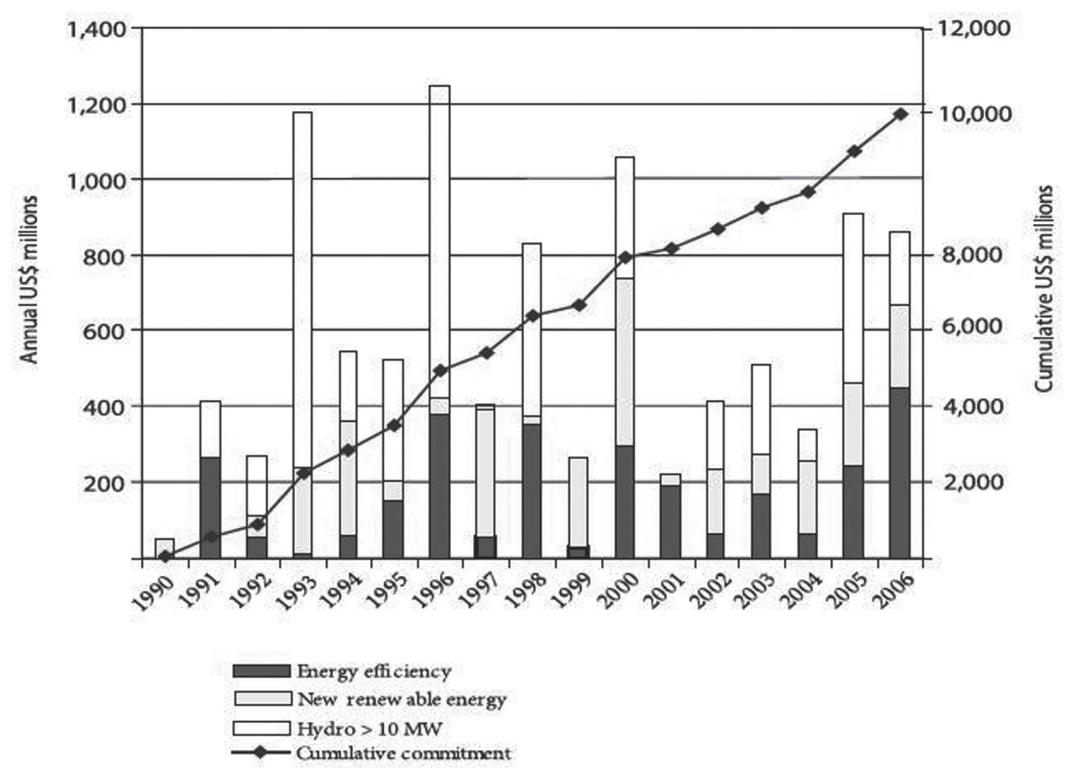

출처: World Bank, 2006b

1990년부터의 세계은행그룹에 의한 에너지 분야 지원 동향을 〈그림 3〉에 나타내었다. 1990년 이 래 세계은행그룹은 대규모 수력을 포함한 재생에너지와 에너지 효율분야에서 100억 달러 이상을 지원하여왔다. 그 중 27억 달러가 신재생에너지 관련 분야에 투입되었으며, $100 \mathrm{MW}$ 를 초과하는 대규모 수력발전에는 총 45억 달러가 사용되었다(World Bank, 2006b).

〈그림 4〉에서 제시된 것처럼 신재생에너지와 에너지효율이 차지하는 비중은 지속적으로 증가하여 왔다. 2006년 세계은행그룹의 재생에너지와 에너지효율 지원의 비중은 전체 에너지 분야 지원의 $19 \%$ 이며 전력분야로 한정할 때는 35\%에 해당한다(World Bank, 2006b). 


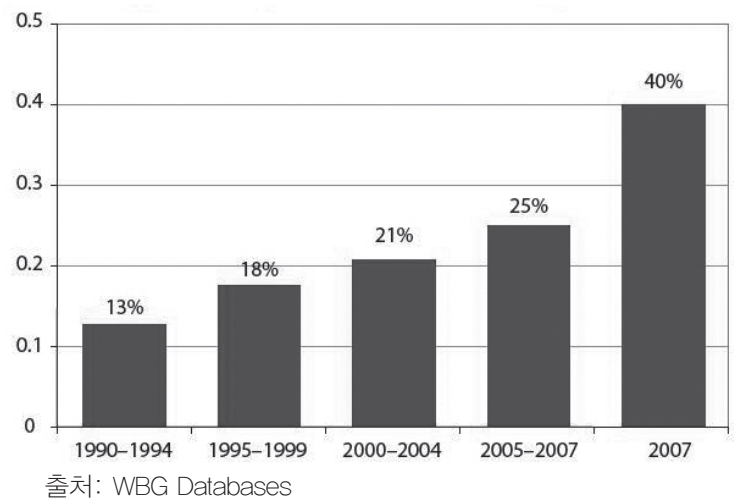

세계은행에 의한 신재생에너지 지원의 지역적 분포를 살펴보면 동아시아 지역을 위한 지원 금액이 제일 많았으며 다음 순위는 남아시아가 차지하였다. 이것은 그간의 지원이 급격한 경제성장을 이루 고 있는 아시아 지역에 집중되었음을 나타낸다. 북아프리카를 제외한 아프리카 지역의 지원은 약 $13 \%$ 에 머물렀으며 무엇보다 1999-2001년도에 최고액을 기록한 후 지속적으로 하락하였다 (표 3). 개발과 경제성장에서 차지하는 에너지의 역할과 전력공급망이 구축되어 있지 않아서 근대적인 에너지를 사용할 수 없는 농촌산간지역에서 독립형 신재생에너지 시스템이 가지는 비교우위 등을 생각하면 많은 인구가 절대빈곤으로 고통 받고 있는 아프리카 지역에서의 신재생에너지 지원 감소 는 우려되는 점이다. 그러나 최근 세계은행은 'Lighting Africa' 프로그램을 추진하며 이러한 문제 점을 해결하고자 하였다.

\section{〈표 3〉지역별 신재생에너지 지원 분포(대규모 수력 재외)}

(백만불)

\begin{tabular}{c|c|c|c|c|c|c|c} 
& '90-'92 & '93-'95 & '96-'98 & '99-'01 & '02-'04 & '05-'06 & 합계 \\
\hline $\begin{array}{c}\text { 아프리카 } \\
\begin{array}{c}\text { 동아시아 및 } \\
\text { 태평양연안 }\end{array}\end{array}$ & 51 & 349 & 114 & 142 & 55 & 232 & 942 \\
\hline 유럽과 중앙아시아 & & & 43 & 130 & 94 & 65 & 357 \\
\hline 라틴아메리카 & 39 & 5 & 22 & 288 & 61 & 71 & 486 \\
\hline 중동 및 북아프리카 & & 4 & & & 40 & 6 & 50 \\
\hline 남아시아 & 2 & 222 & 29 & 112 & 146 & 44 & 554 \\
\hline 전 지구적 & & & 175 & 22 & 14 & & 212 \\
\hline 합계 & 114 & 586 & 398 & 709 & 297 & 439 & 2708 \\
\hline
\end{tabular}

출처: World Bank, 2006b

태양광, 풍력 등 신재생에너지를 이용한 발전 분야뿐만 아니라 발광다이오드(Light Emitting Diodes, LEDs), 절전형 소형 형광등(Compact Fluorescent Lamps, CFLs)과 같이 조명기구 분야 
에서도 기술 혁신이 있어왔다. 이에 아프리카의 5 억에 이르는 에너지 빈곤층이 이러한 해택을 누릴 수 있도록 할 필요성이 증가하였다. 'Lighting Africa'는 사하라이남 지역의 2억5,000만 명의 인 구가 2030년까지 비화석연료를 사용하는 저비용 고품질의, 안전하고, 믿을 수 있는 조명 제품에 접 근할 수 있도록 도와주는 이니셔티브로 이 프로그램을 통해 세계은행은 저소득 가구와 사업체에 집 중하면서 농촌뿐만 아니라 도시지역, 도시 근교지역도 지원하고 있다. 이와 병행하여 세계은행은 기업의 진출을 촉진하기 위한 아프리카의 독립형 조명 시장에 대한 연구를 수행하였다. 시장 잠재 성, 소비자의 요구, 조명기구에 대한 취향, 제품 속성과 디자인, 제품 판매 채널등과 같은 시장조사 뿐만 아니라 저에너지 조명기구의 활용을 통한 $\mathrm{CDM}$ 사업의 활성화를 위한 연구를 진행하고 있다. 2008년 5월에는 가나의 아크라에서 제1회 Lighting Africa 컨퍼런스를 개최하며 아프리카 내의 협력국 뿐만 아니라 다른 공여기관 등의 참여를 이끌어내고 있다(World Bank, 2008).

세계은행그룹의 재생에너지 및 에너지효율 정책은 양측으로 진행된다. 한쪽에서는 중단기의 에 너지 공급을 위해 노력하며 다른 쪽에서는 장기간에 걸친 신재생에너지의 지속적인 보급 확대를 위한 정책 개발과 역량 강화를 추진한다. 이는 상위에서의 분석적, 조언적 활동(Analytical and Advisoty Activities)을 주요 요소로 삼는데 종종 이런 AAA 지원은 세계은행의 투자에 통합된다. 그 좋은 예로 인도에서의 장기적인 에너지 문제 연구, 솔로몬제도에서의 재생에너지 연구 등을 들 수 있다. 기술지원 또한 세계은행의 신재생에너지 지원에서 중요한 부분인데 이를 위해 다양한 워 크샵, 컨설팅, 훈련 프로그램 등이 제공되고 있다.

에너지 분야에서의 저탄소 노력이 지속적으로 이루어질 수 있도록 세계은행그룹은 국가 차원 에서의 개발전략 문서에 이를 통합하여왔다. 2004-2006년에 완성된 총 86개의 국가지원전략 (Country Assistance Strategy, CAS)과 빈곤감소전략(Poverty Reduction Strategic Paper, $\mathrm{PRSP}$ )을 검토한 결과 재생에너지와 에너지 효율을 비중있게 언급한 것이 2004년에 40\%에서 2006년에 88\%로 증가하였다(World Bank, 2006b). CAS와 같은 계획 문서에서 가능성 있는 관련 투자 기회를 발굴하는 것은 미래의 재생에너지 및 에너지효율 분야의 투자를 가늠할 수 있는 훌륭 한 지표가 된다는 점에서 매우 중요하다. 세계은행은 앞으로도 재생에너지를 개발 전략에 통합하기 위한 지원을 지속할 것을 발표하였다.

2005년에 세계은행그룹은 개도국에서의 에너지 접근 문제를 해결하고 저탄소개발을 달성하 기 위한 방안을 마련하기 위한 방법으로 '청정에너지 및 개발투자 체제 (Clean Energy and Development Investment Framework, $\mathrm{CEDIF})^{\prime}$ 를 준비하기 시작하였다. 개발을 위한 에너지 및 빈곤층의 에너지 접근 향상과 저탄소경제로의 이행, 적응을 주요 골자로 하는 $\mathrm{CEDIF}$ 에서 에너 지 효율과 재생에너지는 중요한 부분을 차지한다. $\mathrm{CEDIF}$ 에서 개발을 위한 에너지 및 빈곤층의 에 
너지 접근의 향상을 위한 노력은 사하라이남의 아프리카 지역에 집중된다. 사하라이남의 아프리카 는 근대적인 에너지공급의 혜택을 받지 못하는 주민이 대부분이며 취사와 난방을 위해 목재연료나 동물의 배설물을 사용하고 있는 지역으로서, '아프리카 에너지 확보계획 (Africa Energy Access Plan)'의 방침에 따라 이 지역에서의 지원 사업이 실시될 것이다. 아프리카 에너지 확보계획은 (1) 취사, 난방과 조명을 위한 청정 연료에의 접근, (2) 전력공급 확대, (3) 지역개발 프로젝트를 포함 하여 새로운 지역에 에너지를 제공하기 위한 추가적인 발전 용량 제공, (4) 학교와 병원 등 중요 공 공시설의 에너지 공급 (5) 전력망이 닿지 않는 곳에 거주하는 가구들을 위한 독립형 전등 장비 제공 등의 내용을 담고 있다.

또한 세계은행그룹은 최근 급격한 경제성장으로 많은 양의 에너지를 소비하는 국가에서의 에너지 효율 향상을 위한 사업을 지원하고 있는데, 브라질, 중국, 인도, 멕시코, 남아프리카 등을 주된 대 상으로 한다. 이들 신흥성장국가들이 저탄소 사회로 전환할 수 있도록 협력관계를 공고히 하기위해 노력하고 있으며, 특히 이들 국가에서의 신재생에너지 활성화를 위한 장기 에너지 정책 수립 등을 지원하고 있다.

\section{2. 유럽연합 (EU)}

유럽연합(EU)은 여전히 많은 빈곤층이 기본적인 에너지를 안정적으로 공급받지 못하고 있는 상황 을 인식하고 이를 해결하기 위해 "빈곤퇴치 및 지속가능 개발을 위한 유럽연합 에너지 이니셔티브 (EU Energy Initiative for Poverty Eradication and Sustainable Development, EUEI)'를 추 진하기로 하였다. 이것은 2002년 9월 요하네스버그에서 개최된 '지구정상회의 (World Summit on Sustainable Development)'에서 비롯되었으며, 개도국에 지속가능한 에너지를 공급하기위한 EU 회원국들과 $\mathrm{EC}$ 의 노력을 나타낸다.

$\mathrm{EUEI}$ 는 개도국의 경제적, 사회적, 환경적 목표를 달성하기 위해서 에너지 분야에서 필요한 여러 조치들을 실행하는 것을 제안하였는데, 이 중에는 신재생에너지의 보급 증가 등이 포함되어 있다. 먼저 EUEI의 목적은 (1) 빈곤감소를 위한 에너지 역할의 중요성에 대한 고위급에서의 인식 제고, (2) 빈곤감소와 지속가능한 성장을 위한 에너지 부분 서비스의 구체적인 필요성 발굴, (3) 국가 및 지역 개발 정책에서 에너지 수요를 명확히 하는 것, (4) 에너지와 연관된 행위들의 시너지 창출, 그 리고 (5) 민간부분, 금융 시장, 소비자들로부터 새로운 자본, 기술, 인적자원의 활용을 자극하고 개 도국의 참여가 가능하도록 하는 것이다. 이러한 목적을 위해 ODA는 기본적인 자금의 틀을 제공하 고 적합한 민관협력 방식을 통해 근대적이고 깨끗한 에너지의 보급 확대를 추진하고자 한다. 
EUEI의 지원방향은 과거 EU의 에너지 지원 동향을 분석한 후 이를 보완하는 식으로 수립된 점이 눈에 띤다. EU는 1997년부터 2001년까지 에너지 분야 전체에서 ODA 형태로 매해 평균 7억9,500 만 달러를 지원하여 왔으며, 2001년 동 분야의 지원규모는 12 억2,400만 달러에 이른다 (그림 5). 전체 에너지 분야에서 수력이 차지하는 비율은 $16.5 \%$ 이며 그 외의 재생에너지가 차지한 비율은 $14.7 \%$ 이었다. 특히 개도국에서 대부분의 빈곤층이 주변의 바이오매스나 목재를 사용하여 난방과 취사를 해결하면서 발생하는 호흡기 질환 및 유기질비료 부족의 문제가 심각한데도 불구하고 이 부 분에 대한 지원은 전체의 $1 \%$ 미만에 그치고 있다. 이러한 검토 결과를 바탕으로 유럽의 여러 나라 들은 $\mathrm{EUEI}$ 를 통해 재생에너지의 사용 확대와 깨끗하고 친환경적인 난방 및 취사 기구의 보급을 위 해 노력하고 있다.

〈그림 5〉 $\mathrm{EU}$ 의 에너지분야 지원 흐름 (EUEl 설립 전)

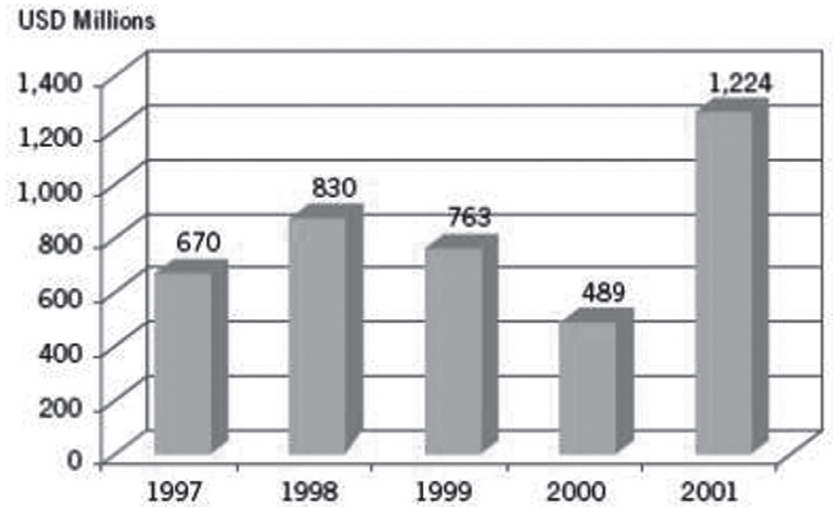

(출처: $\mathrm{EC}, 2003$ )

〈그림 6〉세부분야별 에너지 관련 지원 (EUEI 설립 전)

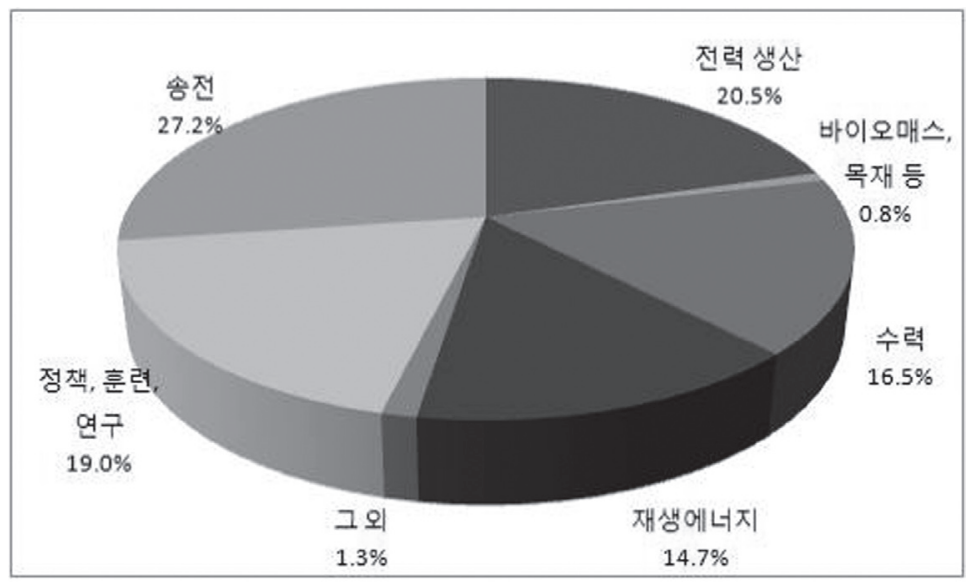

(출처: $\mathrm{EC}, 2003)$ 


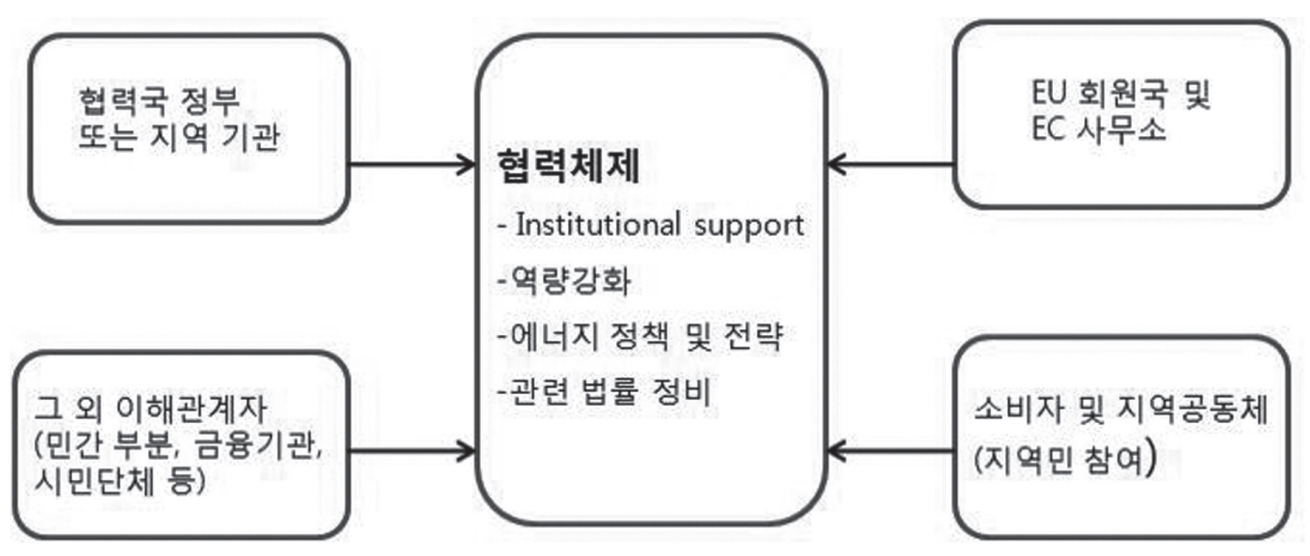

EUEI는 성공적인 사업추진을 위해〈그림 7〉과 같은 협력체제를 구축한다. 이러한 협력체제에서 수원국 정부기관 뿐만 아니라 민간사업자, 금융기관, 시민단체 등 폭넓은 이해관계자들이 사업 진 행을 위해 의견을 개진할 수 있다. 이러한 협력체제를 통해서 사업대상지의 특성과 상황에 가장 적 합한 최상의 방식을 찾고자 한다. EUEI에서의 협력은 추진하고자 하는 프로그램 또는 사업의 해당 국가, 해당 지역에 국한되지 않고, 다른 국제적인 에너지 관련 지원체제와 ${ }^{6}$ 의 협력 관계도 수립하 여 왔다 (EC, 2003).

\section{IV. 주요 DAC 공여국의 지원 동향 및 전략}

$\mathrm{OECD} \mathrm{DAC} \mathrm{통계시스템의} \mathrm{원조목적코드로} \mathrm{등록되어} \mathrm{있는} \mathrm{신재생에너지의} \mathrm{종류에는} \mathrm{재생에너지로}$ 생산된 전력, 수력, 풍력, 태양에너지, 지열, 바이오매스, 해양에너지가 있다. 이들 중 개발도상국 에서 가장 역사가 깊은 재생에너지원으로서 주로 농촌 지역의 전력을 담당해 온 수력에 대한 지원 이 압도적으로 많았다 (그림 8). 현재까지 활용 가능한 전체 소수력 용량의 $10 \%$ 만이 개발된 상태이 기 때문에, 소수력의 개발 잠재력은 상당하다고 할 수 있다. 다만, $10 \mathrm{MW}$ 이상의 대수력 개발이 야 기하는 생태학적 및 사회적 영향에 대한 우려를 고려하여, 소수력 위주의 지원을 수행해야 한다는 의견도 있다.

6) Forum of Energy Minister of Africa, the New Partnership for Africa's Development, Johannesburg Renewable Energy Coalition, UN Commission for Sustainable Development 등 
〈그림 8〉 2007년 OECD DAC에 등록된 신재생에너지 분야별 지원 승인액 (백만불)

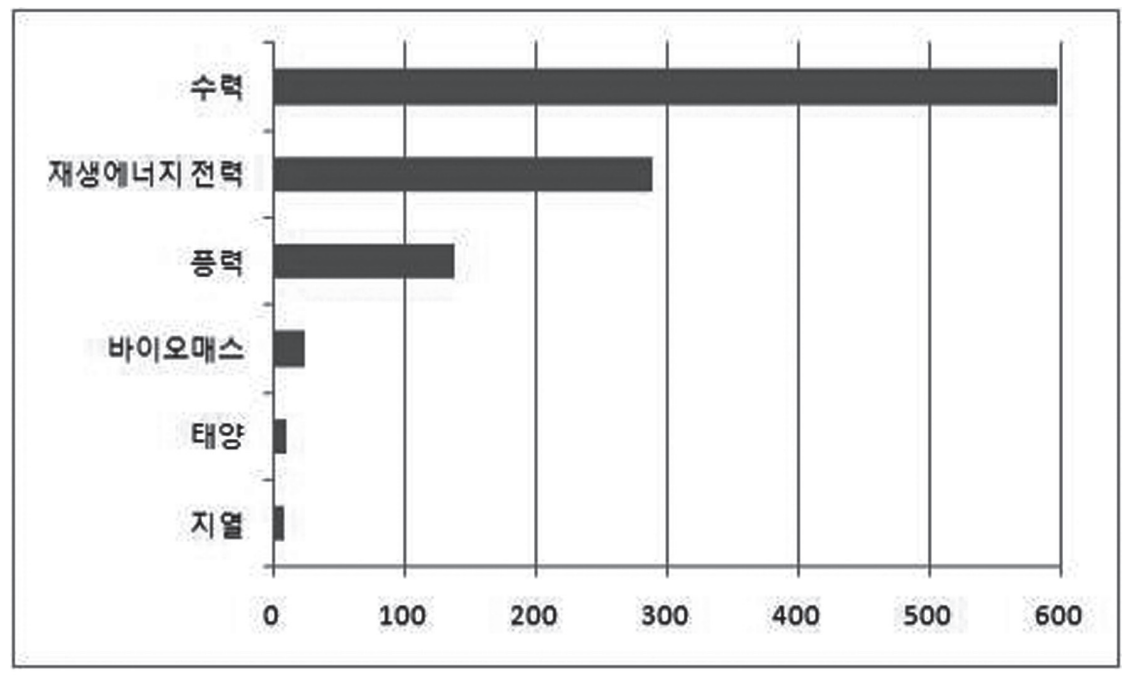

국별 신재생에너지 지원 현황을 살펴보면, 독일과 일본이 주요 지원 국가이며, 풍력을 중심으로 신 재생에너지를 지원하는 스페인도 상당한 금액을 지원하고 있다 (그림 9). 개발도상국에 대한 신재 생에너지 지원은 계속 증가하는 추세에 있어, 2000년 약 9억 불이던 지원 금액이 2007년에는 약 28억 불로 증가하였다 (그림 10). 특히 2004년 이후 증가세가 뚜렷하게 관찰되는데, 이는 교토의 정서의 발효 이후 온실가스 감축을 위한 방안으로 신재생에너지가 각광을 받게 되면서 나타난 현상 인 것으로 풀이된다.

〈그림 9〉2007년 OECD DAC에 등록된 국가별 신재생에너지 분야 지원 승인액 (백만불)

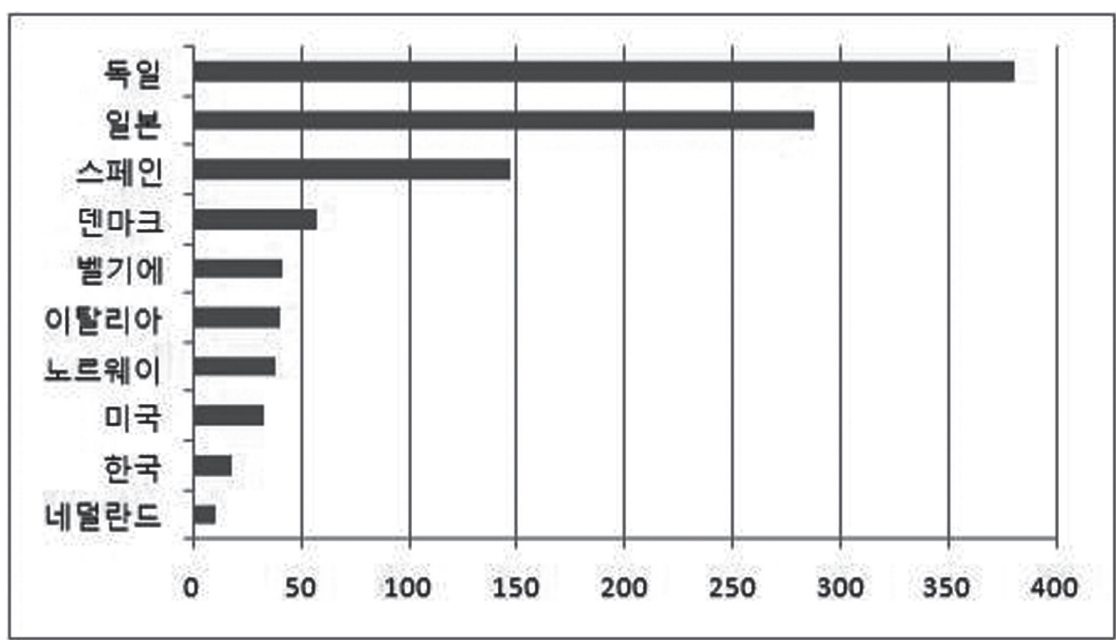




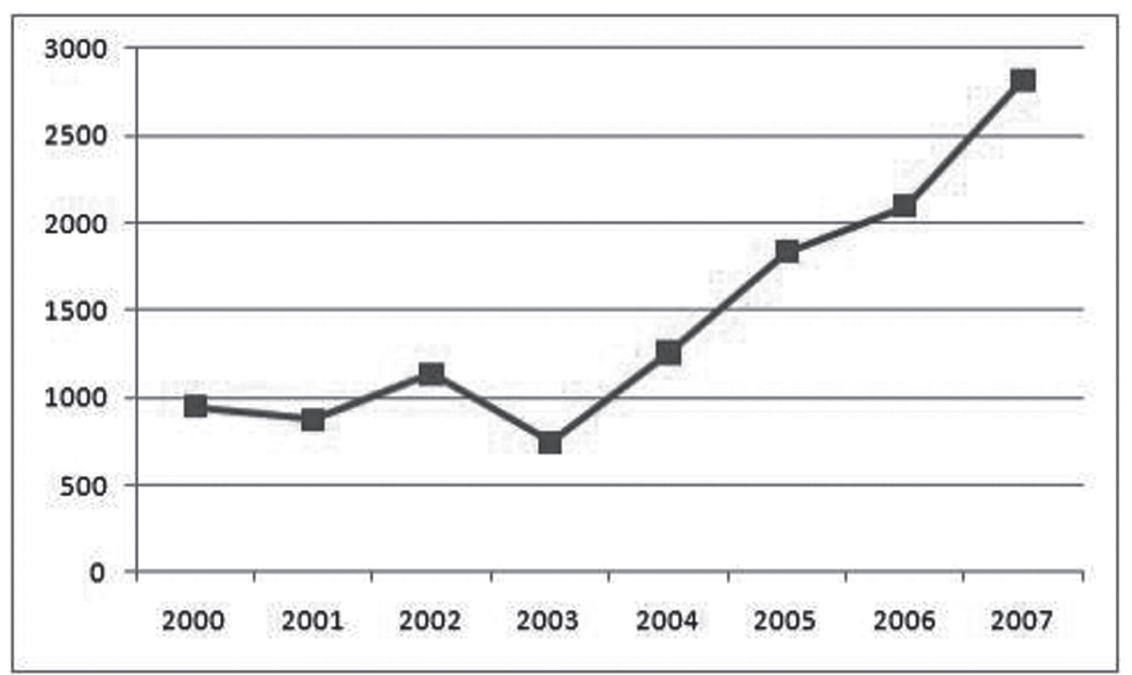

\section{1. 일본}

1997년 제3차 기후변화협약 당사국총회에서 일본은 '교토 이니셔티브’를 발표하며 ODA를 통한 개 도국의 기후변화 대응 노력을 촉구하였다. 교토 이니셔티브에서 3개의 큰 축은 (1) 수원국의 기후 변화 관련 역량 강화 (2) 최상의 양허조건으로 제공되는 ODA 차관 (3) 일본기술의 효과적인 사용 및 기술이전으로 이러한 원칙에 입각하여 일본은 1998년부터 2005년까지 대기오염, 폐기물 처리, 에너지효율, 산림 분야에서 1 만 5,000 여 명에게 연수프로그램을 실시하였고 지구온난화에 대응하 기 위해 1997년 12월부터 2006년 3월까지 모두 92개의 프로젝트에 1조1,410억 엔의 차관을 투입 하였다(한국국제협력단, 2009).

2000-2004년 동안 일본은 물, 농업, 산림, 환경보호 뿐 만 아니라 에너지 분야에서도 세계 1 위의 공여국 이었다. 동 기간에 $\mathrm{OECD}$ 의 $\mathrm{DAC}$ 회원국들이 에너지 분야에 지원한 금액은 141 억 달러이었 으며, 일본은 $50 \%$ 를 차지하여 1 위를 기록하였고 이는 2 위인 미국에 의한 지원 금액의 두 배를 약 간 넘어선다. 앞서 살펴 본 2007년 신재생에너지 부문 지원 금액도 2 억8,500만 불을 기록하여 독 일에 이어 두 번째로 많이 신재생에너지 분야에 대한 지원을 실시했음을 알 수 있다.

일본의 기후변화 대응 지원은 지속가능한 발전에도 기여하는 Co-benefit 형을 추구한다. 에너지 분야는 $\mathrm{Co}$-benefit형 기후변화 대책에 깊게 연관되는 분야이다. JICA의 전력 분야 지원은 그 동안 개도국의 발전소 건설 타당성 조사와 관련 인력 양성 등이 중심이 되었다. 그러나 최근 개도국 정 부의 역할도 많은 선진국들과 마찬가지로 전력 사업을 실시하는 주체에서 민간에 의한 전력 개발을 
지도하는 주체로 변화하고 있기에 JICA도 민간 주도에 의한 전력의 안정적 공급을 위한 정책 입안 과 관련 제도 정비에 대한 지원을 중시하고 있으며, 이를 통해 신재생에너지의 보급 확대를 지원하 고자 한다.

그리고 2008년 1월, 후쿠다 총리의 ‘Cool Earth Partnership 추진구상' 발표에 따라 일본 정부의 $\mathrm{ODA}$ 추진방향은 (1) 온실가스 감축과 경제성장의 동시 달성을 위해 개도국과 일본정부의 정책대 화를 통하여 협력 실시 (2) 개도국의 경제성장과 주민의 삶의 질 향상 및 온실가스 저감을 양립하는 개발원조 접근 (3) 일본의 발달된 기술을 적극적으로 활용 (4) 국제사회에 공헌하는 연구 추진으로 정해졌다. 2008년에서 2012년까지 기후변화 대응을 위해 100억 달러의 기금 조성을 공약한 Cool Earth Partnership은 전기를 사용하지 못하는 개도국이 태양광과 소수력 등의 신재생에너지를 활 용하여 농촌전력화 및 경제발전을 달성할 수 있도록 지원하는 파트너십이다. 특히 청정에너지 접근 성 향상의 관점에서 지열이용 지방전력화 사업조사 및 온난화대책을 위한 Co-benefit 원조사업 등 을 추진하며, 이의 성공을 위해 환경부 등과 기술협력을 실시하고 있다.

일본 신재생에너지 지원의 가장 큰 특징은 $\mathrm{ODA}$ 자금을 활용한 $\mathrm{CDM}$ 사업이다. 일본은 $\mathrm{CDM}$ 사업 에 $\mathrm{ODA}$ 자금을 이용하는 것을 지속적으로 찬성해 온 국가로서, 이집트 홍해 연안에 $120 \mathrm{MW}$ 용량 의 풍력발전소를 건설하면서 매해 20 만톤의 이산화탄소 감축 효과를 이룩한 자파라타 풍력발전소 건설 사업을 2007 년 6 월에 $\mathrm{CDM}$ 사업으로 등록하여 승인받았다. 이 사업은 ODA 자금을 이용한 최초의 대규모 신재생에너지 분야의 $\mathrm{CDM}$ 이 되었으며, 일본정부는 $\mathrm{ODA}$ 를 활용한 $\mathrm{CDM}$ 사업의 추 진을 앞으로도 계속 찬성할 것으로 밝혔다.

\section{2. 독일}

세계 1 위의 태양광 전지 생산 업체를 보유하고 있으며, 풍력 발전 설비 누적량 또한 세계 1 위인 독 일은 2008년 신재생에너지 보급 확산을 위한 국제기구 IRENA의 창설에 주도적인 역할을 하였다. IRENA는 지난 1월 26일에 독일의 본(Bonn)에서 창립총회를 개최하였으며 독일의 연방환경장관 과 연방경제개발협력 장관이 의장을 맡았다. IRENA는 개도국에서의 신재생에너지의 보급 확산도 지원할 것이며 선진국과 개도국의 관련 정책 틀의 개선과 역량 강화를 지원한다. 그리고 신재생에 너지의 잠재성, 재정 메커니즘, 관련 첨단 기술 등에 대한 정확한 정보 제공도 수행하고 있다.

$\mathrm{GTZ}$ 는 농촌산간지방 주민들의 낮은 에너지 접근성을 향상시키고, 화석연료를 사용하여 전기를 생

7) www.mofa.go.jp/policy/oda/white/2007/ODA2007html/box/bx01001.htm 
산하는 과정에서 발생하는 온실가스로 야기되는 지역적인 오염을 줄일 수 있는 방안으로 재생에너 지의 사용을 제안하였다. GTZ가 제공하는 서비스로는 (1) 소수력, 태양광, 태양열 등과 같은 재생 에너지 시스템 설치 지원, 2) 에너지효율이 높은 가전제품 특히 스토브의 기술 개발 및 보급, (3) 재 조림과 산림 관리를 통한 에너지 안보 구축 지원, (4) 에너지 문제에 대한 인식 제고, 그리고 (5) 공 공기관과 중소기업에서의 에너지효율 향상에 기여하는 기술의 촉진이 있다.

2006년 한 해 동안 에너지 절약형 스토브 보급사업으로 22 만톤의 이산화탄소의 배출 감소라는 성 과를 달성하였으며, 태양광을 이용한 펌핑 시스템 설치 사업을 통해 농촌산간지방의 전력화와 생산 성 향상을 추진해 왔다. 이러한 재생에너지 확대를 위한 전략으로 다음 두 가지를 추진하고 있다: (1) 정부 프로그램: 산간지방의 병원, 학교, 식수공급시스템에 태양광 발전설비를 지원하는 것과 같이 사회 기본 시설에 재생에너지를 활용한 전력화를 지원하여 개개인의 만족도를 높이는 것, (2) 시장 주도적인 확산 정책: 시장시스템을 통한 농촌산간지역의 전력화는 공급자, 투자자, 금융기관 등 다양한 그룹의 상호작용 촉구 (GTZ, 2009).

\section{3. 미국}

USAID는 지속가능한 성장과 친기후적인 기술의 응용에서 기술적 전문성을 갖출 수 있도록 지 원하는 것을 목표로 산업, 교통 등 여러 분야에서 에너지 관련 활동을 수행하고 있다. 민간 투자 의 활성화, 관련 정책 개혁, 기술 접근 향상에 기여하고 에너지 효율, 신재생에너지 사용, 메탄 포 집 등의 분야에서 역량 강화를 위한 지원 활동을 펼쳐왔다. 이를 통해 USAID는 지난 5 년간 1,500 만 톤의 이산화탄소 감축을 달성하였다. 중점 지원대상국 중의 하나는 세계 6 위의 이산화탄소 배 출국인 인도이다. 인도에서는 USAID의 지원으로 전력효율 및 환경보호 센터 (Center for Power Efficiency and Environment Protection)가 설립되었다.

USAID는 빈곤가구에서 에너지비용이 생활비의 상당부분을 차지하는 것을 인식하고 저비용의 태 양열 온수 시스템의 보급을 남아프리카에 지원하고 있다. 이를 통해 실내오염감소와 온실가스 배출 감소를 동시에 달성하였으며 성공적인 사업 수행으로 남아프리카 국가 차원에서 관심이 증대하여 주택 관련 정부기관 등과 협력하여 프로그램의 확대 실시를 추진하고 있다. ${ }^{8)}$

아메리카 재생에너지 이니셔티브 (Renewable Energy in the Americas Initiative)는 라틴아메 리카와 카리브 지역의 개도국에서의 신재생에너지 보급 확산을 위해 출발하였으며, 그 결과물로

8) www.usaid.gov/our_work/environment/climate/policies_prog/ghg.html

9) http://www.usaid.gov/our_work/economic_growth_and_trade/energy/publications/projects/ lamerica_reia.pdf 
는 전세계 마을에너지 파트너십 (Global Village Energy Partnership, GVEP) 활동을 조직하고 촉진하기 위한 성공적인 GVEP-LAC(라틴아메리카 카리브) 컨퍼런스 실행을 먼저 꼽을 수 있다. 그 외의 성과로는 동 지역의 9 개 국가에서 '지역 에너지 실행 계획'의 초안 작성을 지원한 것, 과 테말라에서 243 개의 태양광시스템과 한 개의 $156 \mathrm{~kW}$ 소수력 발전소를 건설한 것, GEF, UNEP, $\mathrm{AFD}, \mathrm{FFEM}$ 에서 총 150만 달러에 이르는 자금을 '동카리브 지열개발사업 (Eastern Caribbean Geothermal Development Project)'과 관련하여 지원받은 것 등을 들 수 있다.

이러한 사업 추진을 통해 REAI는 사업의 구상을 위한 지역의 다양한 이해관계자의 참여 및 여러 방 면에서 기술지원을 제공할 수 있는 기관과의 협력이 중요하다는 교훈을 얻게 되었다. 아울러 무엇 보다 수원국의 고위급관계자를 참여시키는 것을 강조한다. 이는 과테말라에서 재생에너지 법안을 통과시키는 데 장장 5 년의 기간이 필요하였던 경험으로부터 얻은 교훈으로서, 원조기관의 의지도 중요하지만 수원국의 의지가 반드시 함께 존재하여야 장기간 동안 지속적인 사업을 추진할 수 있기 때문이다.

$\mathrm{REAI}$ 의 대표적인 프로그램 및 지원 분야는 아래와 같다.

\section{1) GVEP-LAC}

지역 조정자로서의 역할을 수행하고 있으며, 볼리비아, 페루, 브라질, 과테말라, 온두라스, 도미니 카 공화국, 에콰도르, 멕시코 등에서 마을 에너지 실행 계획의 수립을 지원하였다.

\section{2) 에너지 정책 분석 및 개정}

지속가능한 에너지 서비스의 보급은 적절한 에너지 및 전력 정책에 의존한다. 이것은 폭넓은 전력 구조 정책 (예를 들어, 민간의 참여 허용 범위, 전략, 개발 정책 등)과 신재생에너지를 위한 정책을 포함한다. 전년도에 과테말라와 그레나다에서 이와 같은 사업을 수행하였다.

\section{3) GSEII}

군소도서국의 지속가능한 개발계획에 재생에너지와 에너지효율 프로젝트, 모델, 사업 개념을 포함 하도록 군소도서국 정부와 잠정 공여기관의 협력을 이끌어내는 것을 목적으로 한다. REAI의 최근 지원은 성 루시아(St. Lucia), 그레나다와 도미니카에 집중하였다. 


\section{4) 동카리브 지열에너지 개발사업}

카리브에 위치하는 도미니카, 성 루시아(St. Lucia) 등과 협력하여 지열발전을 위한 역량강화, 지 열 에너지 분포 평가, 정책 개정 등을 통한 지열발전의 확산을 위해 노력하고 관련 장벽 제거를 위 한 하나의 방안으로 지열 굴착 위험 펀드를 창설하였다.

\section{4. 영국}

2009년 7월 의회에 발표된 'Eliminating World Poverty: Building Our Common Future’에서 $\mathrm{DFID}$ 는 저탄소성장을 위한 지원의 확대를 제시하였다. 이 제안서에 의하면 영국정부는 '환경전환 펀드 (Environmental Transformation Fund)'를 통해서 개도국에 신재생에너지 지원을 수행할 것이다. 그 방안으로 개도국에서의 신재생에너지 수요 창출을 위한 시장 기법 개발을 지원하며 중 저소득 국가들 및 국제기구들과 협력하여 저탄소 기술에 대한 투자를 늘리고 민관협력을 통한 새로 운 파트너십 구축으로 혁신을 이끌어갈 것을 공표하였다. 그리고 2012년까지 청정기술펀드 (Clean Technology Fund)에 지원하는 영국의 지원금은 이산화탄소 발생량이 급격하게 증가하고 있는 15-20개국에 대한 신재생에너지 지원과 에너지효율 향상, 대중교통 설립 등에 쓰일 것이다(DFID, 2009).

재생에너지 증대프로그램 (Scaling-up Renewable Energy Programme)은 5-8개의 저소득국 가에서 신재생에너지의 보급 확산을 추진하며, 특히 제조업 등 생산 산업 분야와 소비자들에게 신 재생에너지 보급 확산을 중점적으로 지원할 것이다. 그리하여 2015년까지 250만 가구에 신재생에 너지를 보급하고 수입 디젤의 소비를 줄이는 것을 목표로 하고 있다. 또한 개발은행들이 신재생에 너지 지원 비중을 확대할 수 있도록 적극 지원할 것이다. 예를 들어 유럽부흥개발은행 (European Bank for Reconstruction and Development)의 신재생에너지 지원 비중을 80\%까지 확대하겠다 는 목표치를 제시하였다.

저탄소성장이라는 혁신을 이루기 위해 영국정부는 적어도 3개국에 파일럿 센터를 설립할 계획이 다. 이 센터들은 저탄소성장의 국가적 구심점으로 역할을 수행할 수 있도록 운영될 것이며, 이를 통 해 민간투자 활성화 및 협력국의 신성장 동력 개발과 일자리 창출을 이끌어내고자 한다.

개도국에서 대규모 태양광 또는 풍력발전설비의 설치를 확대하기 위해서는 민간을 끌어들일 인센 티브가 필요하다. 이러한 인센티브의 하나는 생산된 신재생에너지의 안정적인 가격인데 DFID는 이 를 위해 Advanced Market Commitments를 제안하였다. 이는 신재생에너지 사업에 투자한 민간 
회사들이 장기간에 걸쳐 안정적으로 투자수익을 회수할 수 있도록 하는 장치이다.

\section{V. 결론 및 제언}

신재생에너지 지원의 효과는 MDGs 상에 명시적으로 제시되어 있지 않지만, 거의 모든 MDG 목표 와 직간접적인 관계를 맺고 있어 개발도상국의 빈곤퇴치에 매우 중요한 작용을 하는 것으로 분석되 었다. 또한 온실가스 농도를 안정화 시켜 기후변화를 완화하는 한편, 에너지 빈곤층에게는 지속가 능한 전력과 에너지를 제공한다는 측면에서 신재생에너지의 지원은 중요성을 지니게 된다.

선진 공여기관의 신재생에너지 분야 지원은 IBRD, IDA 등 세계은행그룹을 중심으로 이루어져 왔 다. 세계은행은 개발도상국이 기후변화의 영향을 줄이기 위해 지출해야 하는 비용이 현재 연평균 80 억 불에서 2030 년까지 4,000 억 불로 급증할 것으로 전망한다. 이와 같이 막대한 기후변화 비용 을 선진국 정부의 공적자금 만으로 충당하는 것은 불가능하며, 따라서 다양한 민간자본을 유도하여 기후변화 분야의 투자를 확장할 필요가 있다. 이에 세계은행은 탄소펀드를 활발히 구성하여 특히 개발도상국의 신재생에너지 지원에 주력하고 있다. 또한 원조기관을 중심으로 한 선진국들도 각종 이니셔티브나 파트너십을 구성하여 신재생에너지 지원을 수행 중이다.

그 간 $\mathrm{KOICA}$ 는 라오스, 아프가니스탄, 이라크 등지에 대한 소수력 사업에 한하여 신재생에너지 지 원 사업을 일부 실시해 왔지만, 여타 신재생에너지에 대한 지원은 전무한 실정이다. 하지만 갈수록 높아지는 기후변화에 대한 국제적 관심 및 2009년부터 KOICA가 집행하게 된 동아시아기후파트너 십의 성격을 고려할 때, $\mathrm{KOICA}$ 의 다변화된 신재생에너지 지원이 지속적으로 요구될 것이다. 이 때 개발도상국의 수요와 여건에 맞는 $\mathrm{KOICA}$ 자체의 신재생에너지 지원 모델이 필요하다. 예컨대, 중 앙 전력망으로부터 멀리 떨어져 있으면서 근시일 내에 전력망이 보급될 계획이 없는 격지에는 독립 형 전력 시스템을 지원하되, 각 지역의 자연 여건 및 사용자들의 생활양식을 고려한 신재생에너지 원을 선택해야 한다. 반면에 국가 전체에 전력망 구축이 미흡하여 전반적으로 전력이 부족한 경우 에는 대규모의 계통연계형 시스템을 고안하여 지원하는 것이 합당하다.

선진 원조기관들의 신재생에너지 지원 사례를 검토한 결과, 단일 프로젝트 지원보다는 관련 시장 창출, 제도 정비, 인력 교육·훈련, 부대시설 건립 등을 포함한 프로그램형 지원이 더 성공적인 효 과를 가져온다는 사실을 발견하였다. 세계은행이 필리핀에 지원한 '지속가능한 태양광 시장 종합정 책’ 또는 아프리카를 위한 'Lighting Africa'가 성공적인 신재생에너지 분야의 프로그램형 지원 사 
례이다. 아직 프로젝트 중심으로 진행되고 있는 $\mathrm{KOICA}$ 의 신재생에너지 사업들을 프로그램형의 지 원으로 점차 발전시켜야 할 필요가 여기에 있다.

개발도상국을 위한 신재생에너지 지원의 당위성은 앞서 밝힌 바와 같이 환경, 자원고갈, 에너지안 보의 관점에서 찾을 수 있다. 하지만, 점차 기술집약적인 분야로 거듭나는 신재생에너지 분야가 또 다른 위험요소가 되어 아직 기술적으로 성숙하지 않은 개발도상국에게 에너지 고립현상을 야기하 지 않도록 적절한 기술이전 등을 동반한 지원의 실시가 요구된다. 


\section{참고자료}

\section{1. 국내문헌}

김대환, 박희수, 임소영. 2009. 「국제개발협력 분야별 민관협력 활성화 방안 - 기 후변화 분야」.『국제개발협력』2009년 통권 3호: 72 96면. 성남:한국 국제협력단

한국국제협력단. 2008. 『국제개발협력의 이해』. 성남:한국국제협력단 한국국제협력단 기후변화대응반. 2009. ${ }^{\circledR} \mathrm{DAC}$ 주요 원조기관별 기후변화 대응 분 야 사업전략 조사자료집』. 성남:한국국제협력단

\section{2. 국외문헌}

Department for International Development. 2009. Eliminating World Poverty: Building our Common Future. Norwich: The Stationery Office.

Enskat, M., Bernhard, Z., Kuhne, R. 2009. GTZ Energy News No. 10. Eschborm: GTZ.

European Commission. 2003. The EU Energy Initiative: Energy for Poverty Eradication and Sustainable Development, Luxembourg; European Commission.

European Commission. 2007. Communication from the Commission to the Council, the European Parliament, the European Economic and Social Committee and the Committee of the Regions, Limiting Global Climate Change to 2 Degrees Celsius The Way Ahead for 2020 and Beyond, Brussels

IEA. 2008. World Energy Outlook 2008, Paris: International Energy Agency.

IEA. 2009. Key World Energy Statistics, Paris: International Energy Agency.

World Bank. 2006a. New Renewable Energy: A Review of the World Bank's Assistance, Washington, DC: World Bank.

World Bank. 2006b. Improving Lives: World Bank Group Progress on Renewable Energy and Energy Efficiency Fiscal Year 2006, Washington, DC: World Bank.

World Bank. 2008. Lighting Africa Year 1: Progress and Plans Annual Report, Washington, DC: World Bank. 